\title{
OBJECTIVE EVALUATION OF PATIENTS WITH RHEUMATIC DISEASES. II. PAPER ELECTROPHORETIC STUDIES OF SERUM GLYCO- PROTEIN AND PROTEIN FROM PATIENTS WITH RHEUMATOID ARTHRITIS ${ }^{1}$
}

\author{
By GEORGE STIDWORTHY, R. W. PAYNE, ClARA L. SHETLAR, AND \\ M. R. SHETLAR \\ (From the Research Laboratory, VA Hospital, and the Departments of Biochemistry and \\ Pharmacology, University of Oklahoma School of Medicine, Oklahoma City, Okla.)
}

(Submitted for publication September 13, 1956; accepted November 7, 1956)

Serum glycoprotein concentrations serve as a valuable index of the intensity of inflammatory activity in the rheumatic diseases (1), particularly when the glycoprotein level is considered in relation to the serum protein with which it is bound, i.e., as the polysaccharide protein ratio $(\mathrm{PR})$. The typical changes of serum protein (lowering of albumin, increase of globulin) in rheumatoid arthritis are well known (2).

The development of techniques for serum protein and glycoprotein analyses by filter paper electrophoresis permits a detailed study of the changes in each of the serum protein components as well as the distribution of carbohydrate bound to these components (3). The relationship of these various components to the severity of inflammatory activity of rheumatoid arthritis has consequently been investigated.

1 These studies were supported in part by grants from Geigy Pharmaceuticals Division of Geigy Chemical Corporation, Ardsley, N. Y., and from the Oklahoma Chapter of the Arthritis and Rheumatism Foundation with funds made available by the United Fund of Oklahoma City.

\section{METHODS}

Laboratory. Paper strip electrophoresis was performed essentially as described by Block, Durrum, and Zweig (4) using Durrum type cells (Spinco Model R). Electrophoretic runs were made at room temperature $\left(78^{\circ}\right.$ to $85^{\circ}$ ) for 16 hours on Whatman $3 \mathrm{MM}$ filter paper strips saturated with $0.075 \mathrm{M}$ Barbital buffer ( $\mathrm{pH}$ 8.6) using a constant current of 5 milliamps for each cell of 8 strips. A volume of 10 microliters was applied to the paper for protein fractionations and 30 microliters for glycoprotein separations. All samples were run in duplicate. Protein was visualized on the paper strips by staining with bromophenol blue-zinc sulfate as described by Block, Durrum, and Zweig (4). The glycoprotein color development on the paper strips was accomplished by the Periodic-acid Schiff reaction largely as described by Koiw and Gronwall (5). However, the reducing solution was prepared as described by Roboz, Hess, and Forster (6).

Quantitation of the developed strips was made with a servo type recording photometer and automatic integrator (Spinco Model R Analytrol). Protein strips were scanned through blue filters, glycoprotein strips through green filters (Klett 52). The total area under the protein curve was equated to the total serum protein as determined by the biuret reaction of Weichselbaum and Shapiro (7), and the glycoprotein curve to the total serum glycoprotein as determined by the tryptophan

TABLE I

Serum protein fractions as estimated by paper electrophoresis

\begin{tabular}{|c|c|c|c|c|c|c|}
\hline \multirow[b]{2}{*}{ Group } & \multirow[b]{2}{*}{ No. } & \multicolumn{5}{|c|}{ Protein as per cent of total protein of } \\
\hline & & Albumin & $\alpha_{1}$ & $\alpha_{2}$ & $\beta$ & $\gamma$ \\
\hline Normal & 13 & $57.3 \pm 1.7 \ddagger$ & $4.9 \pm 0.3$ & $9.4 \pm 0.7$ & $11.9 \pm 0.6$ & $16.3 \pm 1.3$ \\
\hline \multicolumn{7}{|l|}{ Rheumatoid arthritis } \\
\hline $\begin{array}{l}\text { Clinical activity } 1 \\
\text { Clinical activity } 2 \\
\text { Clinical activity } 3 \text { and } 4 \dagger\end{array}$ & $\begin{array}{r}8 \\
13 \\
12\end{array}$ & $\begin{array}{l}49.5^{*} \pm 0.8 \\
44.9^{*} \pm 1.2 \\
39.5^{*} \pm 2.0\end{array}$ & $\begin{array}{l}5.3 \pm 0.4 \\
6.4^{*} \pm 0.4 \\
6.8^{*} \pm 0.3\end{array}$ & $\begin{array}{l}10.6 \pm 0.6 \\
11.1^{*} \pm 0.4 \\
14.7^{*} \pm 0.5\end{array}$ & $\begin{array}{l}13.7 \pm 0.1 \\
14.3^{*} \pm 0.6 \\
15.4^{*} \pm 0.6\end{array}$ & $\begin{array}{l}20.9 \pm 1.4 \\
23.3^{*} \pm 1.2 \\
23.7^{*} \pm 2.3\end{array}$ \\
\hline
\end{tabular}

* Significantly different from the normal group at the $1 \%$ level of probability.

+ Composed of eight with activity 3 and four with activity 4 .

$\ddagger$ Figures following the \pm sign are standard errors of the mean of each group. 
TABLE II

Protein bound polysaccharide $\dagger$ of serum fractions as estimated by paper electrophoresis

\begin{tabular}{|c|c|c|c|c|c|c|c|c|c|c|}
\hline & \multirow[b]{2}{*}{ No. } & \multicolumn{9}{|c|}{ Mg. \% of polysaccharide of } \\
\hline & & Total & Albumin & & $\alpha_{1}$ & $\alpha$ & & $\beta$ & $\gamma$ & Seromucoid \\
\hline Normal & 13 & $115 \pm 4.1$ & $14.8 \pm 0.7$ & 16.3 & \pm 0.9 & 33.6 & \pm 2.3 & $28.3 \pm 1$ & $3 \quad 22.5 \pm 1.3$ & $11.0 \pm 1.4$ \\
\hline \multicolumn{11}{|l|}{ Rh. arthritis } \\
\hline \multirow[t]{3}{*}{$\begin{array}{l}\text { Clin. activity } 1 \\
\text { Clin. activity } 2 \\
\text { Clin. activity } 3 \text { and } 4 \ddagger\end{array}$} & $\begin{array}{r}8 \\
13 \\
12 \\
\end{array}$ & $\begin{array}{l}150^{*} \pm 3.6 \\
176^{*} \pm 14.6 \\
197^{*} \pm 5.9\end{array}$ & $\begin{array}{l}14.7 \pm 1.1 \\
14.3 \pm 1.8 \\
14.2 \pm 0.9\end{array}$ & $\begin{array}{l}19.7 \\
28.0 \\
34.5\end{array}$ & $\begin{array}{l}* \pm 1.3 \\
* \pm 1.7 \\
* \pm 3.0\end{array}$ & $\begin{array}{l}51.9^{*} \\
66.6^{*} \\
81.1^{*}\end{array}$ & $\begin{array}{l} \pm 2.5 \\
\pm 2.9 \\
\pm 3.9\end{array}$ & $\begin{array}{l}35.9^{*} \pm 1 \\
36.7^{*} \pm 1 \\
37.6^{*} \pm 3\end{array}$ & $\begin{array}{ll}.6 & 27.8 \pm 1.8 \\
4 & 29.0 \pm 2.5 \\
2 & 29.1 \pm 2.2\end{array}$ & $\begin{array}{l}20.5^{*} \pm 1.6 \\
30.5^{*} \pm 1.7 \\
30.3^{*} \pm 0.8\end{array}$ \\
\hline & & \multicolumn{9}{|c|}{ Polysaccharide as per cent of the protein (PR) of } \\
\hline & No. & $\begin{array}{l}\text { Total } \\
\text { protein }\end{array}$ & Albumin & & $a$ & 1 & & $\alpha_{2}$ & $\beta$ & $\gamma$ \\
\hline Normal & 13 & $1.48 \pm 0.03$ & $0.33 \pm 0.0$ & & $4.27=$ & \pm 0.28 & 4.67 & \pm 0.30 & $3.04 \pm 0.21$ & $1.81 \pm 0.09$ \\
\hline \multicolumn{11}{|l|}{ Rh. arthritis } \\
\hline $\begin{array}{l}\text { Clin. activity } 1 \\
\text { Clin. activity } 2 \\
\text { Clin. activity } 3 \text { and } 4 \ddagger\end{array}$ & $\begin{array}{r}8 \\
13 \\
12\end{array}$ & $\begin{array}{l}1.91^{*} \pm 0.03 \\
2.26^{*} \pm 0.06 \\
2.73^{*} \pm 0.06\end{array}$ & $\begin{array}{l}0.37 \pm 0.0 \\
0.41 \pm 0.0 \\
0.52 * \pm 0.0\end{array}$ & & $\begin{array}{l}4.84^{*}= \\
5.89^{*}= \\
6.96^{*}=\end{array}$ & $\begin{array}{l} \pm 0.11 \\
\pm 0.16 \\
\pm 0.40\end{array}$ & $\begin{array}{l}6.29 \\
7.87 \\
7.93\end{array}$ & $\begin{array}{l}* 0.35 \\
* \pm 0.44 \\
* 0.32\end{array}$ & $\begin{array}{l}3.47 \pm 0.31 \\
3.42 \pm 0.16 \\
3.32 \pm 0.26\end{array}$ & $\begin{array}{l}1.79 \pm 0.21 \\
1.61 \pm 0.13 \\
1.77 \pm 0.13\end{array}$ \\
\hline
\end{tabular}

* Significantly different from the normal group at the 1 per cent level of probability.

$\dagger$ Bound hexose as determined by the tryptophan method (8). Hexosamine component of the polysaccharide complex is not included.

$\ddagger$ Composed of eight with activity 3 and four with activity 4 .

method of Shetlar, Foster, and Everett (8). The quantitations of individual fractions were made by calculating the percentage of the total area contributed by the areas representing each of the various fractions. The areas representing each of the glycoprotein fractions were selected by comparing the glycoprotein densitometer curve with the corresponding protein curve.

Seromucoid was determined by the method of Weimer and Moshin (9).

Clinical. An estimate of clinical activity of the rheumatoid process was assigned at each clinic visit as described in a previous report (10). Current disease activity was thus grossly appraised as:

Activity $1-$ No inflammatory activity

Activity 2-Mild activity

Activity 3-Moderate activity

Activity 4-Severe activity

\section{RESULTS}

Results of the analyses of the serum protein and glycoprotein fractions from patients with rheumatoid arthritis of various degrees of severity are summarized in Tables I and II. Typical electrophoretic strips of a normal serum are depicted in Figure 1, and those of a patient with severe rhenmatoid arthritis in Figure 2.

With increasing severity of the rheumatoid process an increase occurred in all the globulin fractions, being most marked in the $\alpha_{2}$ globulin.
A corresponding significant decrease in the serum albumin fractions occurred; indeed it would appear that the decreasing serum albumin is a slightly more sensitive index of activity than the serum globulin increase.

The most striking changes in serum glycoprotein of patients with rheumatoid arthritis occurred in those carbohydrate moieties associated with the $\alpha_{1}$ and $\alpha_{2}$ protein fractions. This increase is in excess of the protein increase in the $\alpha_{1}$ and $\alpha_{2}$ fractions, resulting in an increased percentage of bound carbohydrate in these fractions (Table II). On the other hand the increases in the $\beta$ and $\gamma$ fractions merely parallel the changes in protein contents of these respective fractions.

Correlation coefficients of protein, seromucoid and glycoprotein fractions with clinical activity of the rheumatoid arthritis patients are presented in Table III. Clinical activity was found to have a significant positive correlation with total PR, $\alpha_{1}$ and $\alpha_{2}$ glycoprotein, seromucoid and $\alpha_{2}$ globulin protein, and a negative correlation with serum albumin. Seromucoid exhibited significant correlation with total glycoprotein (expressed either as mg. per cent or as PR) and with $\alpha_{1}$ and $\alpha_{2}$ glycoprotein. The total PR was correlated with the PR's of the $\alpha_{1}$ and $\alpha_{2}$ globulins. Total glycoprotein (in $\mathrm{mg}$. per $100 \mathrm{ml}$.) exhibited a low but sig- 


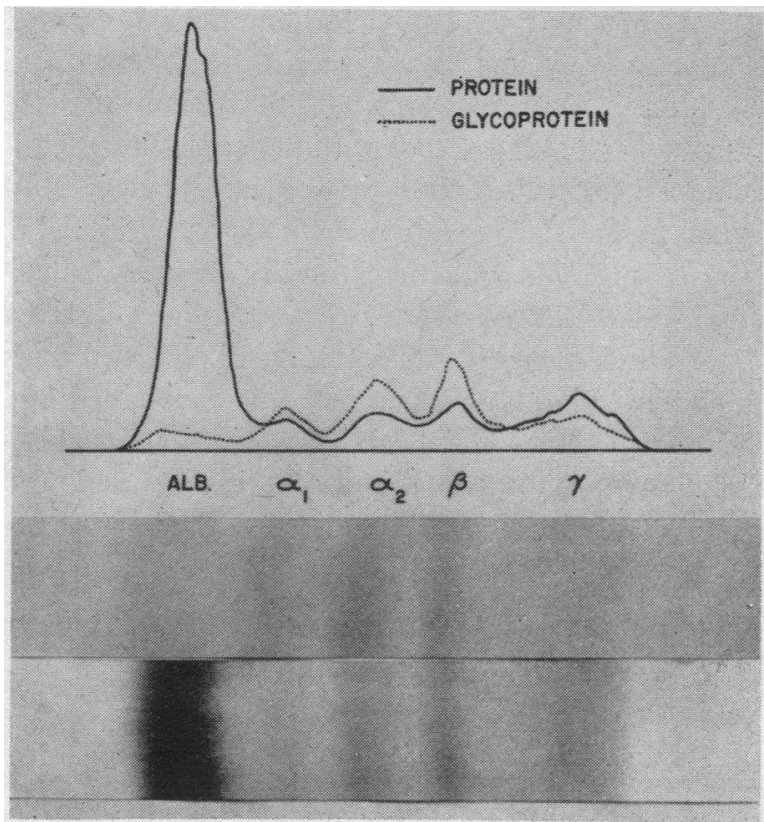

Fig. 1. Typical Paper Strip Electrophoretic Patterns of Normal Serum with Corresponding DensiTOMETER TRACINGS

The solid line indicates protein concentration; the dotted line, glycoprotein concentration. The top strip is stained with Periodic-acid Schiff reagents for glycoprotein and the bottom with bromophenol blue for protein.

The total hexose glycoprotein of this serum was 108 mg. per $100 \mathrm{ml}$. distributed among the fractions as follows: Albumin, $13.2 \mathrm{mg}$. per $100 \mathrm{ml}$; $\alpha_{1}, 14.5 ; \alpha_{2}, 27.6$; $\beta, 30.2$; and $\gamma, 22.4$. The total protein of this sample was 7.42 grams per $100 \mathrm{ml}$.

nificant correlation with $\alpha_{1}$ glycoprotein, but not with $\alpha_{2}$ glycoprotein.

\section{DISCUSSION}

Changes in serum protein produced by various types of rheumatic diseases have been reported. The data of Table I are confirmatory of earlier work in which a decrease of serum albumin, and an elevation of the globulin fractions was noted. The observation that serum albumin as determined by a 26 per cent sodium sulfate salting out procedure has a negative correlation with activity of rheumatoid arthritis (11) is further confirmed by paper electrophoresis studies (Table III). The correlation coefficient of -0.526 for the salting out method is very close to the -0.563 found in the present study. Use of the electrophoretic method allows further investigation of relationships between clinical activity and protein fractions. The finding of a positive correlation of 0.635 for $\alpha_{2}$ globulin with clinical activity is of interest, as elevations of this fraction have been noted in many inflammatory conditions. No other protein fraction was significantly correlated with activity. It may be implied that albumin and $\alpha_{2}$ globulin fractions are more rapidly affected than are other fractions by inflammatory activity in rheumatoid arthritis insofar as their protein moieties are concerned.

The concentration of serum glycoprotein in patients with rheumatoid arthritis serves as an index of the inflammatory activity of this disease. As can be seen in Table II the most striking elevation of serum glycoprotein in patients with rheumatoid arthritis is found in carbohydrate bound

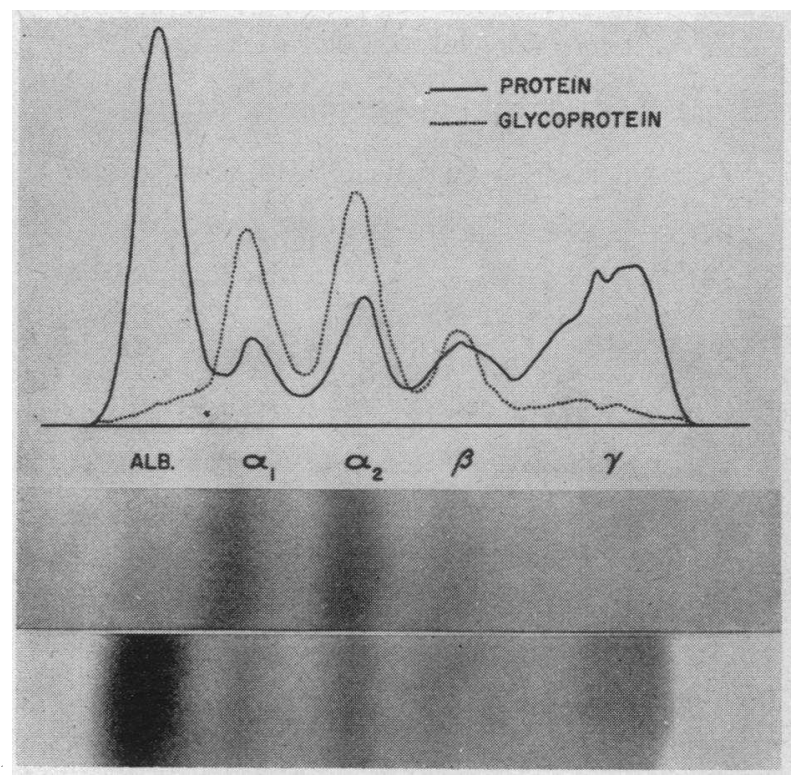

Fig. 2. Typical Paper Strip Electrophoretic Patterns and Corresponding Densitometer Tracings of the Serum of a Patient with Active Rheumatoid ARThritis

The solid line indicates protein concentration; the dotted line, glycoprotein concentration. The top strip is stained with Periodic-acid Schiff reagents for glycoprotein and the bottom strip with bromophenol blue for protein.

Total hexose glycoprotein of this serum was $208 . \mathrm{mg}$. per $100 \mathrm{ml}$. distributed among the fractions as follows: Albumin, $9.6 \mathrm{mg}$. per $100 \mathrm{ml}$; $\alpha_{1}, 63.4 ; \alpha_{2}, 79.7 ; \beta, 33.7$; and $\gamma, 21.6$. Total protein of this sample was 7.22 grams per $100 \mathrm{ml}$. 
TABLE III

Summary of correlation coefficients

$=\quad r^{*} \quad$ t Valuet $P$

\begin{tabular}{lrrr}
\hline \multicolumn{4}{c}{ Correlation with clinical activity } \\
Total PR $\ddagger$ & 0.914 & 12.50 & .01 \\
$\alpha_{1}$ PR $\ddagger$ & 0.559 & 3.75 & .01 \\
$\alpha_{2}$ PR $\ddagger$ & 0.296 & 1.72 & .10 \\
Albumin \% of total protein & -0.563 & 3.79 & .01 \\
$\alpha_{1} \%$ of total protein & 0.110 & 0.64 & .30 \\
$\alpha_{2} \%$ of total protein & 0.635 & 4.58 & .01 \\
$\beta \%$ of total protein & 0.183 & 1.34 & .15 \\
$\gamma \%$ of total protein & 0.306 & 1.79 & .10 \\
$\alpha_{1}$ polysaccharide, mg. \% & 0.654 & 4.82 & .01 \\
$\alpha_{2}$ polysaccharide, mg. \% & 0.684 & 5.21 & .01 \\
Seromucoid & 0.689 & 3.49 & .01
\end{tabular}

Correlation with seromucoid

\begin{tabular}{|c|c|c|c|}
\hline $\begin{array}{l}\text { Total PR } \ddagger \\
\text { Total polysaccharide, mg. } \% \\
\text { Alb. polysaccharide, mg. } \% \\
\alpha_{1} \text { polysaccharide, mg. } \% \\
\alpha_{2} \text { polysaccharide, mg. } \% \\
\beta \text { polysaccharide, mg. } \% \\
\gamma \text { polysaccharide, mg. } \%\end{array}$ & $\begin{array}{r}0.786 \\
0.826 \\
-0.224 \\
0.826 \\
0.603 \\
0.448 \\
-0.082\end{array}$ & $\begin{array}{l}5.09 \\
3.85 \\
0.92 \\
5.88 \\
3.02 \\
1.69 \\
0.21\end{array}$ & $\begin{array}{l}.01 \\
.01 \\
.25 \\
.01 \\
.01 \\
.15 \\
.45\end{array}$ \\
\hline \multicolumn{4}{|c|}{ Correlation with total polysaccharide } \\
\hline $\begin{array}{l}\alpha_{1} \\
\alpha_{2}\end{array}$ & $\begin{array}{l}0.459 \\
0.114\end{array}$ & $\begin{array}{l}2.88 \\
0.64\end{array}$ & $\begin{array}{l}.01 \\
.35\end{array}$ \\
\hline \multicolumn{4}{|c|}{ Correlation with total polysaccharide protein ratio } \\
\hline $\begin{array}{ll}\alpha_{1} & \text { PR } \ddagger \\
\alpha_{2} & \text { PR } \ddagger\end{array}$ & $\begin{array}{l}0.686 \\
0.706\end{array}$ & $\begin{array}{l}5.24 \\
5.55\end{array}$ & $\begin{array}{l}.01 \\
.01\end{array}$ \\
\hline
\end{tabular}

${ }^{*} \mathrm{r}=$ Correlation coefficient.

$\dagger \mathrm{t}=\frac{\mathrm{n}^{3} \mathrm{r}}{\left(1-\mathrm{r}^{2}\right)^{\frac{1}{3}}} \mathrm{n}=\mathrm{N}-2$.

$\ddagger$ Polysaccharide (bound hexose) as per cent of the protein involved.

to the $\alpha$-globulins. This increase is in excess of $\alpha$-globulin protein increases since there is a disproportionately large percentage of glycoproteins bound to both $\alpha_{1}$ and $\alpha_{2}$ globulins in the active phases of the disease studied. Some of this elevation is probably due to increases in the seromucoids which have electrophoretic mobilities at $\mathrm{pH} 8.6$ similar to the $\alpha$-globulins. Furthermore, the high correlation coefficients of $\alpha_{1}$ globulin carbohydrate (0.826) and $\alpha_{2}$ globulin carbohydrate (0.603) with seromucoid suggest a close relationship of these components in rheumatoid arthritis. However, the seromucoid levels (Table II) are not high enough to account for all of the carbohydrate increases found in the $\alpha_{1}$ and $\alpha_{2}$ fractions. One may, well speculate that carbohydrate rich fractions with mobilities at $\mathrm{pH} 8.6$ similar to $\alpha_{1}$ or $\alpha_{2}$ globulin, as yet not definitely characterized, are elevated in the sera of patients with rheumatoid arthritis:
The carbohydrate bound to albumin was found to be relatively low by the procedure followed in this study. Only slight changes of albumin carbohydrate percentage occurred in patients with rheumatoid arthritis. This is in contrast to data obtained by salt fractionation methods as previously reported (11) in which striking increases of albumin bound carbohydrate were found in active rheumatoid arthritis. The most likely explanation of the disparity between the data obtained by the two methods is that the albumin fraction obtained by salt fractionation contains appreciable amounts of carbohydrate rich globulin, and thus has a higher carbohydrate content.

The significant changes in serum $\alpha_{2}$ globulin, the bound carbohydrate of $\alpha_{1}$ and $\alpha_{2}$ globulin and of seromucoid with increasing clinical activity of rheumatoid arthritis patients are of considerable interest. The technique of filter paper electrophoresis would appear to have advantages in that only minute amounts of serum are required for analysis and the entire spectrum of protein and glycoprotein may be investigated. However, data obtained from total serum polysaccharide-protein ratio as obtained by chemical methods, which are a necessary preliminary to paper strip quantitation, are apparently as satisfactory as any of the fractionation data for use in evaluating activity of the rheumatoid process.

\section{SUM MARY}

Paper electrophoretic techniques have been applied to analyses of serum protein and glycoprotein components from patients with rheumatoid arthritis of various degrees of severity. The increase of serum glycoprotein in patients with rheumatoid arthritis is due to 1) increases of the carbohydrate rich globulin fractions relative to the carbohydrate poor albumin fraction and 2) an increase of the carbohydrate content of the $\alpha_{1}$ and $\alpha_{2}$ globulin fractions.

Changes in the $\alpha$-globulins are apparently most closely related to inflammatory activity in rheumatoid arthritis, as the carbohydrates associated with $\alpha_{1}$ and $\alpha_{2}$ globulin and the $\alpha_{2}$ globulin protein increased with increasing clinical activity. A decrease of albumin protein occurred with increasing severity of the disease. 
Total serum glycoprotein (expressed as hexose polysaccharide as a percentage of the serum protein) exhibited the highest correlation with clinical activity, and consequently is to be recommended as the most satisfactory laboratory method of those studied for evaluation of the status of patients with rheumatoid arthritis.

\section{REFERENCES}

1. Payne, R. W., Shetlar, M. R., Bullock, J. A., Patrick, D. R., Hellbaum, A. A., and Ishmael, W. $K$, The serum polysaccharide protein ratio ( $P R$ ) as a measure of rheumatoid activity. Ann. Int. Med., 1954, 41, 775.

2. Gutman, A. B., The plasma proteins in disease. 15. Rheumatoid arthritis. Advances in Protein Chem., 1948, 4, 218.

3. Shetlar, M. R., Cahill, C., Stidworthy, G., and Shetlar, C. L., Comparison of continuous and strip paper electrophoresis techniques for the study of serum glycoproteins. Proc. Soc. Exper. Biol. \& Med., In press.

4. Block, R. J., Durrum, E. L., and Zweig, G., A manual of paper chromatography and paper electrophoresis, Part II, New York, Academic Press, Inc., 1955.
5. Koiw, E., and Gronwall, A., Staining of proteinbound carbohydrates after electrophoresis of serum on filter paper. Scandinav. J. Clin. \& Lab. Invest., 1952, 44, 244.

6. Roboz, E., Hess, W. C., and Forster, F. M., Determination of serum proteins and serum polysaccharides. Arch. Neurol. \& Psychiat., 1955, 73, 536.

7. Weichselbaum, T. E., and Shapiro, I., A rapid and simple method for the determination of salicylic acid in small amounts of blood plasma. Am. J. Clin. Path. (Tech. Section), 1946, 9, 42.

8. Shetlar, M. R., Foster, J. V., and Everett, M. R., Determination of serum polysaccharides by the tryptophan reaction. Proc. Soc. Exper. Biol. \& Med., 1948, 67, 125.

9. Weimer, H. E., and Moshin, J. R., Serum glycoprotein concentrations in experimental tuberculosis of guinea pigs. Am. Rev. Tuberc., 1953, 68, 594.

10. Shetlar, M. R., Payne, R. W., Padron, J., Felton, F., and Ishmael, W. K., Objective evaluation of patients with rheumatic diseases. I. Comparison of serum glycoprotein, cold hemagglutination, C-reactive protein, and other tests with clinical evaluation. J. Lab. \& Clin. Med., 1956, 48, 194.

11. Shetlar, M. R., Payne, R. W., Bullock, J. A., Patrick, D. R., Hellbaum, A. A., and Ishmael, W. K., Comparative studies of serum polysaccharides in rheumatoid arthritis and degenerative joint disease. J. Clin. Invest., 1953, 32, 1208. 